\title{
GST Reform in Australia: Implications of Estimating Price Elasticities of Demand for Food
}

\section{Crawford School Working Paper 1705 March 2017}

\section{Syed Hasan}

Crawford School of Public Policy, The Australian National University

\section{Mathias Sinning}

Crawford School of Public Policy, The Australian National University

\begin{abstract}
This paper uses detailed information about household supermarket purchases from the Australian Nielsen Homescan Survey to estimate price elasticities of demand for a range of food categories. An instrumental variable strategy is employed to address endogeneity issues. The estimates obtained from our analysis are used to study five scenarios in which the rate of the GST on food categories is increased or in which the tax base is broadened to include currently GST-free categories. Our findings reveal that there is considerable scope for raising revenue by increasing the rate and broadening the tax base. Low-income households (the bottom $40 \%$ of the income distribution) can be compensated for the loss in consumption induced by a tax increase. We demonstrate that increasing the rate of the GST from 10\% to 15\% and broadening the tax base would increase tax revenues by up to $\$ 7.1$ billion, whereas compensating lowincome households would require up to $\$ 2.2$ billion. We also provide a detailed list of tax revenues and compensation payments associated with each food category to allow readers to "build their own tax reform" by choosing the categories that should be taxed.
\end{abstract}




\section{Suggested Citation:}

Hasan, S. and Sinning, M. (2017), GST Reform in Australia: Implications of Estimating Price Elasticities of Demand for Food, Crawford School working paper 1705. Crawford School of Public Policy, The Australian National University.

JEL-Classification: D12, D60, H2

Keywords: Household Consumption, Food Price Elasticity, Tax Reform

\section{Address for Correspondence:}

Name: Mathias Sinning,

Position: Associate Professor

Address: Crawford School of Public Policy, The Australian National University.

Tel: +6126125 1284

Email: Mathias.Sinning@anu.edu.au

Crawford School of Public Policy

College of Asia and the Pacific

The Australian National University

Canberra ACT 0200 Australia

www.anu.edu.au

The Crawford School of Public Policy is the Australian National University's public policy school, serving and influencing Australia, Asia and the Pacific through advanced policy research, graduate and executive education, and policy impact. 


\section{Introduction}

Australia experienced a strong increase in public debt levels after the 2008-09 Global Financial Crisis. ${ }^{1,2}$ Due to the limited scope for public spending cuts, it appears likely that government finances will remain unsustainable in the absence of major tax reforms. ${ }^{3}$ As a consequence, numerous options to increase tax revenue have become a matter of intense debate among economists, policy-makers and the public. Perhaps the most controversial debate has been around a reform of the Goods and Services Tax (GST), currently a $10 \%$ value-added tax on a range of goods and services. ${ }^{4}$ Members of both major parties have made a case for increasing the rate of the GST to $15 \%$ and recent empirical work suggests that such an increase (without broadening the tax base) would increase tax revenues by about $\$ 29.4$ billion (Phillips \& Taylor, 2015). The same study finds that broadening the base (without changing the rate) to cover health, education and water/sewerage would yield $\$ 11.5$ billion, while including currently exempted food categories would raise another $\$ 7.1$ billion. Despite the great potential of a GST reform to mitigate fiscal pressures, governments have been reluctant to make changes to the GST because of its regressive nature and negative public attitudes towards tax increases. ${ }^{5}$

The aim of this paper is to study the potential impact of changes in the GST on food. We use data on household supermarket purchases from the Australian Nielsen Homescan Survey, which includes detailed information about weekly food consumption, sales prices and household characteristics (including household income). We estimate the price elasticity of demand for food in an Almost Ideal Demand System (AIDS) and employ and instrumental variable strategy to address endogeneity issues. Knowledge of the price elasticity of demand for food allows us to consider behavioural responses when calculating tax revenues that would result from an increase in the GST rate or a broadening of the tax base. We also study the compensating variation to determine the payments that would be required to compensate

\footnotetext{
${ }^{1}$ http://www . budget.gov.au/past_budgets.htm.

${ }^{2}$ Net debt is expected to increase to $\$ 317.2$ billion (18.1\% of GDP) in the Financial Year $2016-17$ (Commonwealth of Australia, 2016a).

${ }^{3}$ Sinning (2016) illustrates that the Budget 2016-17 projections of a return to surplus in 2020-21 have not only been very optimistic about future economic growth (3\% per annum over the period 2017-18 to 2019-20) but also about the extent to which economic growth can be translated into higher tax revenues.

${ }^{4}$ GST revenues, which are passed on to State and Territory Governments, amounted to $\$ 59$ billion in the Financial Year 2015-16 (Commonwealth of Australia, 2016b). Australia currently taxes less than 50\% of all goods and services (OECD, 2016).

${ }^{5}$ In 2016, Australian Prime Minister Malcolm Turnbull decided to abandon previous plans to reform the GST: http://www.abc.net.au/news/2016-02-07/malcolm-turnbull-unconvinced-on-gst-hike/7146590.
} 
low-income households (we focus on the bottom $40 \%$ of the income distribution) for their loss in consumption resulting from a GST reform. We consider two alternative approaches to calculate GST revenues and compensation payments. The first approach focuses exclusively on data from the Homescan Survey to estimate price elasticities and to calculate GST revenues and compensation payments. The second approach uses the price elasticity estimates obtained from the Homescan Survey and employs data from the Household Expenditure Survey (HES) of the Australian Bureau of Statistics to calculate GST revenues and compensation payments. In contrast to the Homescan Survey, the HES includes reliable household weights that allow us to obtain representative figures.

We examine five hypothetical scenarios in our analysis: (A) broadening the tax base to include selected food categories that we consider as unhealthy (such as sugar, jams and syrups) or environmentally unfriendly (such as meat and packaged water), (B) broadening the base to include all food categories, (C) increasing the GST rate from $10 \%$ to $15 \%$ without broadening the tax base, (D) increasing the rate to $15 \%$ and broadening the base to include selected food categories, and (E) increasing the rate to $15 \%$ and broadening the base to include all food categories.

The recent economic literature on the taxation of food has typically estimated price elasticities of demand for food to study the potential implications of taxes that aim to improve individual health or promote environmental sustainability. Powell et al. (2013), for example, provide a review of recent US studies that link estimates of the price elasticity of demand for food to body weight outcomes. They conclude that taxes on fast food and subsidies on fruits and vegetables have the potential to reduce obesity. Andreyeva et al. (2010) review 160 studies on the elasticity of demand for major food categories and highlight the potential benefits resulting from a tax on soft drinks. Wirsenius et al. (2011) consider greenhouse gas emissions as a tax base to study consumption taxes on animal food products in the EU and conclude that a tax on the consumption of meat from cattle and sheep alone would account for about $80 \%$ of the potential reduction in greenhouse emissions associated with animal food products. Reisch et al. (2013) also highlight the importance of reducing the consumption of meat as the most important step on the way towards sustainable food consumption.

Understanding how consumers respond to a change in food prices is critical for the design of consumption taxes because taxing certain food categories can affect the health and economic 
well-being of consumers. In particular, imposing a tax on a product that is highly elastic can reduce its consumption significantly. Taxing highly elastic food categories can be beneficial (such as a tax on sugar) or detrimental (such as a tax on fresh vegetables) from a health policy perspective. In contrast, taxing highly inelastic products will not lead to a strong decline in consumption but has the potential to raise tax revenues substantially. The role of taxation in shaping food consumption is particularly relevant for low-income households because they typically spend a larger fraction of their income on food than high-income households. Recent Australian studies have estimated price elasticities of demand for food (Ulubasoglu et al., 2016), studied the effects of taxing sugar-sweetened beverages across different income groups (Sharma et al., 2014), and projected tax revenues resulting from alternative GST reform scenarios (Phillips \& Taylor, 2015). Unfortunately, we still know relatively little about the potential responses of consumers that would result from a reform of the GST on food and the implications for low-income households.

We make several contributions to the literature. First, we take advantage of access to detailed information about weekly household supermarket purchases from the Nielsen Homescan Survey over a three-year period. The survey allows us to estimate price elasticities of demand for a range of food categories. Second, we calculate the potential effects of alternative GST reform scenarios on household consumption. We pay particular attention to heterogeneity in the effects by income level because we cannot simply assume that the effects will be constant across the income distribution. Third, we estimate the potential GST revenues associated with each reform scenario and calculate the payments that would be required to compensate low-income households for the loss in consumption associated with each reform scenario. We provide detailed estimates of GST revenues and compensation payments by food category to avoid making arbitrary decisions about the inclusion of food categories in the tax base. Finally, we perform a range of robustness checks to assess the validity of our results.

Our findings indicate that there is considerable scope for raising revenue by broadening the tax base and increasing the rate, even if the bottom $40 \%$ of the households were compensated for the loss in consumption associated with a GST reform. Our analysis based on Homescan data in combination with HES data reveals that imposing a GST rate of $15 \%$ on all food categories would raise up to $\$ 7.1$ billion, while up to $\$ 2.2$ billion would be required to compensate low-income households. We also present the results of a reform proposal that would involve 
broadening the base to include selected (unhealthy and environmentally unfriendly) food categories and increase the GST rate to $15 \%$, which would raise revenues of about $\$ 3.1$ billion and require $\$ 922$ million to compensate low-income households. Taken together, our findings illustrate that a reform of the GST on food in combination with a compensation of low-income households would reduce fiscal pressures considerably while addressing issues related to the regressive nature of the tax.

The remainder of the paper is organized as follows. Section 2 provides an overview of the data. Our empirical strategy is presented in Section 3. Section 4 includes a discussion of the results. Section 5 concludes.

\section{Data}

Our primary data source is the Nielsen Homescan Survey, a longitudinal survey of households in Australia that provides detailed information about weekly food purchases over the period December 2012 to November 2015. The survey records prices and quantities at the barcode level for all transactions over the sample period together with a set of product characteristics, including product description, category, brand, size, unit, date, place (shop) of purchase and information about whether or not the product is on sale. The survey also contains a range of individual- and household-specific socioeconomic and demographic characteristics. Individual-level characteristics include gender, date of birth, occupation, education, employment status, country of birth, marital status, body weight and height of each household member. Household-level characteristics include household size, household income, information about homeownership and region of residence (postcode area). ${ }^{6}$

Our analysis focuses predominantly on household characteristics and barcode-level information on prices and quantities of food purchases, which can be divided into 35 major food categories. The Homescan Survey includes purchases of 10,794 households over the three-year sample period. We restrict our sample to a balanced panel of 8,394 households and $24,645,163$ individual transactions. We exclude 28,152 transactions referring to non-food purchases. Aggregating daily purchases, which are only observed for a subsample, to a weekly level reduces our sample by 1,366,955 observations. We also drop 1,976,808 transactions that cannot be assigned to any major food category and we exclude 1,730,891 transactions with miss-

\footnotetext{
${ }^{6}$ See Nielsen Corporation (2016) and Sharma et al. (2014) for additional information about the survey.
} 
ing information on household size, household income, relevant product characteristics (price, quantity, size, unit) as well as aggregate-level prices based on food category, quarter of the year and State/Territory. After imposing these sample restrictions, our analysis sample includes 19,542,317 individual transactions of 8,394 households.

We use information about the GST status of food (Commonwealth of Australia, 2016c) to divide the 35 food categories observed in the data into seven food categories that attract GST, 26 food categories that do not attract GST, and two residual categories (one GST-able, one GST-free) that include a very hetergeneous set of items. We do not consider the last two categories in our analysis. ${ }^{7}$ GST-free categories in our data include bread, flour, cereals, pasta and rice, meat and poultry, fish and seafood, canned and bottled fish and seafood, fresh eggs, fresh milk, cheese, butter, oil and cream, yoghurt, other dairy products, fresh fruit, canned and frozen fruit and nuts, fresh vegetables, frozen vegetables, sugar, marmalade, jams and honey, spreads and dips, canned spaghetti and baked beans, packaged waters, tea, coffee, vegetable juice and packed, canned and bottled baby foods and sauces and salad dressings. GST categories in our data are cake, biscuit, pudding and bread mixes, spices, and other food additives, confectionery (including ice cream), frozen prepared meals, soft drinks, mixed fruit, juice and cordials. GST-free categories account for almost three quarters of total food expenditure of a household, reflecting that most of the food in Australia is GST exempt. Table 1 includes summary statistics of quantities and prices of the 33 food categories considered in our analysis. ${ }^{8}$

[Table 1 about here.]

We use data from the Household Expenditure Survey (HES) as a secondary data source in our analysis. The HES was collected by the Australian Bureau of Statistics in 2009-10 and includes information on the expenditure, income, net worth and other characteristics of Australian households. Instead of detailed barcode-level information on household purchases, the survey only contains broad food categories similar to those observed in the Homescan Survey. However, in contrast to the Homescan Survey, the HES provides reliable household weights

\footnotetext{
${ }^{7}$ In the following, we will refer to the categories that attract GST as "GST categories" and the categories that do not attract GST as "GST-free categories".

${ }^{8}$ The quantities of two categories, tea and eggs, are underestimated in our analysis because the reported units of the quantities are ambiguous (such as unit vs. pack) and because the units were not always reported. Our analysis does not include cases in which the unit was unobserved.
} 
that allow us to perform representative GST revenue calculations. The HES includes 9,744 households and 625,651 transactions covering a wide range of goods and services. After dropping non-food categories, fast food and meals eaten out from the data, our analysis sample consists of 281,173 transactions of 9,727 households.

\section{Empirical Strategy}

\subsection{Price Elasticity of Demand}

Empirical demand models rely on a variety of functional forms. The most widely used model is the Almost Ideal Demand System (AIDS) of Deaton \& Muellbauer (1980). The AIDS is a complete demand system with certain desirable properties such as additivity of budget shares, homogeneity and symmetry (Golan et al., 2001). Our empirical strategy is inspired by the functional relationships of the original AIDS model but we do not impose any restrictions on our model parameters and we employ a model specification that accounts for the variation in our data. Specifically, we estimate a model that relates the expenditure share (as a fraction of total food expenditure) of a household on a particular item to its price, the prices of all other items, the total food expenditure and the household size:

$$
w_{i h t}=\alpha+\beta \ln \left(p_{i h t}\right)+\sum_{j \in \mathcal{J}} \gamma_{j} \ln \left(\bar{p}_{j t}\right)+\delta \ln \left(X_{h t}\right)+\rho \ln \left(Z_{h t}\right)+\phi_{i}+\lambda_{t}+u_{i h t},
$$

where $w_{i h t}$ is the expenditure share of household $h(h=1, \ldots, H)$ on item $i(i=1, \ldots, N)$ in food category $k$ (the subscript has been omitted) at time $t(t=1, \ldots, T), p_{i h t}$ is the price of item $i$ and $\bar{p}_{j t}$ refers to the state-level aggregate price of one of the remaining food categories, $j \in \mathcal{J}=\{j=1, \ldots, J \mid j \neq k\} . X_{h t}$ is the total food expenditure of household $h$ at time $t$ and $Z_{h t}$ is the household size. $\phi_{i}$ and $\lambda_{t}$ denote item (barcode) and time (quarter) fixed effects. The inclusion of barcode fixed effects in our model is important because they net out any barcode-specific characteristics (including the quality of a product) that do not change over time. Our estimates are based on weekly data and we include time fixed effects for each quarter to account for changes over the business cycle that affect all households in the same way (such as overall inflation and GDP growth). $u_{i h t}$ is the model error term.

We estimate equation (1) separately for each of the 33 food categories in our data. Because the inclusion of cross-prices in our model is not feasible due to the large number of barcodes 
in our data, we add state-level aggregate prices for each of the remaining food categories. The original AIDS model also includes an aggregate price index, which we capture by the inclusion of (quarterly) time fixed effects in our model. If the conditional expectation of the error term, given the set of covariates included in equation (1), is equal to zero, the price elasticity of demand for the $k$ th food category may be written as $\eta_{k}=\frac{\beta_{k}}{w_{k}}-1$ because $w_{k}=\frac{p_{k} q_{k}}{X} \cdot{ }^{9}$ However, it is likely that the zero conditional expectation assumption is violated because expenditure shares and total expenditure are jointly determined. We address this issue by using household income as an instrument of food expenditure. This approach has typically been employed in the literature (Liviatan, 1961; Banks et al., 1997; Blundell et al., 1998; Bhalotra \& Attfield, 1998; Blundell et al., 2007) and is based on the identifying assumption that household income in a two stage budgeting system affects the expenditure share on food only through its effect on total food expenditure.

As a robustness check, we also use (a modified version of) the Quadratic Almost Ideal Demand System (QUAIDS) of Banks et al. (1997). The QUAIDS includes a quadratic of the logarithm of total food expenditure:

$$
\begin{aligned}
w_{i h t} & =\alpha+\beta \ln \left(p_{i h t}\right)+\sum_{j \in \mathcal{J}} \gamma_{j} \ln \left(\bar{p}_{j t}\right)+\delta_{1} \ln \left(X_{h t}\right)+\delta_{2}\left[\ln \left(X_{h t}\right)\right]^{2}+\rho \ln \left(Z_{h t}\right) \\
& +\phi_{i}+\lambda_{t}+u_{i h t} .
\end{aligned}
$$

When estimating equation (2), we will address endogeneity by using household income and household income squared as instruments for the quadratic function of total food expenditure.

\subsection{GST Revenue}

We employ a simple procedure to calculate GST revenues associated with each reform scenario. Specifically, we calculate tax revenues resulting from a GST reform by comparing revenues before and after the reform. Let $q_{h k}^{b}$ denote the quantity consumed by household $h$ before the reform and let $p_{h k}^{b}$ be the tax-exclusive price before the reform. Then the total amount that Australian households spend on food category $k$ consists of two components: (i) the expected

\footnotetext{
${ }^{9}$ Our analysis focuses on the estimation of uncompensated elasticities, i.e. the effect of a change in the logarithm of the price on the logarithm of the quantity, given that income is held constant. Compensated elasticities take the effect of a price change on real income into account. Clements \& Si (2016) estimate compensated and uncompensated elasticities of demand for food and find that the difference (the income effect) is usually small.
} 
value of household spending, $\mathbb{E}\left(p_{k}^{b} q_{k}^{b}\right)$, and (ii) the total number of households in Australia, $H_{A}$. Combining terms yields the tax revenue associated with food category $k$ before the reform:

$$
R_{k}^{b}=\mathbb{E}\left(p_{k}^{b} q_{k}^{b}\right) H_{A} \tau_{k}^{b}
$$

where $\tau_{k}^{b}$ is the tax rate before the reform. To determine the tax revenue after the reform, we need to consider the percentage change in the quantity consumed as a result of the reform. The percentage change in the quantity consumed is based on the elasticity of demand, $\eta_{k}$, which measures the percentage change in consumption caused by a one-percent change in the price, and a term capturing the change in taxation, $\Delta \tau_{k}=\frac{\tau_{k}^{a}-\tau_{k}^{b}}{1+\tau_{k}^{b}}$, where $\tau_{k}^{a}$ is the tax rate after the reform. Then the tax revenue after the reform may be written as

$$
R_{k}^{a}=\mathbb{E}\left(p_{k}^{b} q_{k}^{b}\right)\left[1+\eta_{k} \Delta \tau_{k}\right] H_{A} \tau_{k}^{a}
$$

The additional tax revenue arising from the reform is given by the difference between revenues before and after the reform:

$$
R_{k}=R_{k}^{a}-R_{k}^{b}=\mathbb{E}\left(p_{k}^{b} q_{k}^{b}\right) H_{A}\left[\left(1+\eta_{k} \Delta \tau_{k}\right) \tau_{k}^{a}-\tau_{k}^{b}\right]
$$

Finally, the total revenue is given by $R=\sum_{k=1}^{K} R_{k}$, where $K=J+1$ is the total number of food categories. We estimate the price elasticity of demand by $\widehat{\eta}_{k}=\frac{\widehat{\beta}_{k}}{\bar{w}_{k}}-1$, where $\widehat{\beta}_{k}$ is an estimate of $\beta$ based on one of the models specified in Section 3.1 and $\bar{w}_{k}=$ $(H T)^{-1} \sum_{h=1}^{H} \sum_{t=1}^{T} w_{h k t}$. We can estimate $\mathbb{E}\left(p_{k}^{b} q_{k}^{b}\right)$ by $\overline{p_{k} q_{k}}=(H T)^{-1} \sum_{h=1}^{H} \sum_{t=1}^{T} p_{h k t} q_{h k t}$, using the prices and quantities provided in our data. The total number of households in Australia in 2014 reported by the Australian Bureau of Statistics is 8,902,436 (Australian Bureau of Statistics, 2015).

It is important to note that our GST revenue calculations are based on the assumption that consumer responses to taxation are equivalent to consumer responses to price changes. $\mathrm{Li}$ et al. (2014) study the effect of changes in gasoline prices and gasoline taxes on consumption and find that consumers respond more strongly to gasoline tax changes. They provide two explanations for the stronger response. First, consumers may be more sensitive to taxation because they consider tax changes to be more persistent than price changes. Therefore, the long-run responses to (permanent) tax changes could be greater than to (temporary) price 
changes. Second, tax changes may be more salient than price changes (see, e.g., Chetty et al., 2009), which is less likely to be an issue in Australia because price tags in supermarkets are tax-inclusive. However, the findings of Li et al. (2014) suggest that responses to tax changes may still be greater due to the strong coverage of tax changes in the media. Against this background, the GST revenue estimates presented in this paper may be viewed as upper bound.

\subsection{The Impact of Price Changes on Household Welfare}

A GST reform affects household welfare through its effect on real income. We are particularly interested in the impact of a GST reform on low-income households. Quantifying the impact of price changes on household income allows us to calculate the amount that would be required to compensate low-income households for the income losses induced by a GST reform. We use a conservative definition of low-income households by considering households in the bottom $40 \%$ of the income distribution as low-income households. ${ }^{10}$

A widely accepted approach to summarize the impact of a price change on household welfare is to calculate two monetary measures of welfare change, the equivalent variation (EV) and the compensating variation $(\mathrm{CV})$. The EV measures the change in a consumer's net worth that would have the same welfare impact as a price change. The CV measures the amount that would be required to shift a consumer back to the original welfare level before the price change (Mas-Colell et al., 1995). We are interested in calculating the CV associated with a price change because it allows us to determine the amount that would be required to compensate households.

We can use the prices and quantities provided in our data to calculate the CV. Formally, given the price vector $P=\left(p_{1}, p_{2}, \ldots, p_{N}\right)^{\prime}$, we define $E_{h}$ as the minimum expenditure (including savings, which may be viewed as future consumption) of household $h$ to reach a certain utility level $u_{h}$. Using the superscript 0 (1) to indicate the observed value of a variable before (after) the price change, the CV may be written as (Ferreira et al., 2013):

$$
C V=E_{h}\left(P^{1}, u_{h}^{0}\right)-E_{h}\left(P^{0}, u_{h}^{0}\right) \approx \sum_{i=1}^{N} p_{i} q_{i h} \frac{\Delta p_{i}}{p_{i}},
$$

\footnotetext{
${ }^{10}$ This is in line with a recent report prepared by the Parliamentary Budget Office, which indicates that the income of the bottom $40 \%$ of households in Australia is lower than their expenditure (Commonwealth of Australia, 2015).
} 
where $q_{i h}$ is the quantity of item $i$ consumed by household $h$. Assuming a perfectly elastic supply curve, we can estimate the $\mathrm{CV}$ for each household for any proportional price change. For example, we may consider a household that spends $\$ 100$ on an item that attracts $10 \%$ GST. For this household, an increase in the GST rate to $15 \%$ will result in a welfare loss of $\$ 100 \times(1.15-1.10) / 1.10 \approx \$ 4.55$. The following section presents our price elasticity estimates, discusses the impact of price changes on food consumption and reports the GST revenue and CV calculations for alternative reform scenarios.

\section{Results}

\subsection{Elasticity Estimates}

The estimated price elasticities of demand for 33 food categories are presented in Table 2. The table also includes aggregated elasticities for all food categories by GST type (GST categories vs. GST-free categories) and an overall estimate for all food categories. The OLS and IV estimates obtained from both the AIDS and the QUAIDS model do not differ qualitatively from each other but the IV estimates are more likely to be insignificant because the IV estimator is less efficient than the OLS estimator. In the following, we will focus on the IV estimates because they account for endogeneity of total food consumption. Moreover, we prefer the estimates obtained from the AIDS model because the standard errors of the QUAIDS model are slightly higher due to collinearity of the model regressors. ${ }^{11}$

Our estimates indicate that the overall elasticity of the GST categories is lower than the overall elasticity of the GST-free categories. This finding is interesting because one might have expected that the food categories that attract GST are less necessary and therefore more elastic. The detailed estimates indicate that a few very elastic categories, such as meat and poultry, fish and seafood, fresh vegetables and baby foods are responsible for the large overall price elasticity of GST-free categories. It is possible that consumers are more sensitive to price changes in these categories because their average prices are quite high (see Table 1).

Our elasticity estimates are roughly in line with findings from other studies. Andreyeva et al. (2010) report US price elasticity estimates from 160 studies over the period 1938-2007 by food category, which show that most elasticities are between 0 and -1 and confirm that

\footnotetext{
${ }^{11}$ The first stage estimates of the IV regressions, which vary across food categories, indicate that our instruments are strong in all cases. The first stage estimates are available from the authors upon request.
} 
certain food categories (such as soft drinks, meat, fruits and vegetables) are quite elastic, while others (such as fats/oils, sweets/sugars and eggs) are quite inelastic. The price elasticities of the food categories presented by Andreyeva et al. (2010) are consistent with those presented in Table 2, with the exception of juice, which appears to be more price elastic in the US than in Australia.

[Table 2 about here.]

Table 3 provides a ranking of food categories by the size of their elasticities, ranging from very elastic to very inelastic. The rankings of OLS and IV estimates reveal that the conclusions drawn from the two approaches are very similar. The rankings also show that food categories that may be viewed as more unhealthy (such as sugar, marmalade, jams and syrups or spreads and dips) tend to be more inelastic, while food categories that are more healthy (such as fresh fruit and vegetables) tend to be more elastic.

[Table 3 about here.]

In the following analysis, we will consider the implications of a GST reform that involves broadening the tax base to include food categories that we consider as unhealthy or environmentally unfriendly - the bold categories in Table 3. Most of these food categories are relatively inelastic (and therefore have the potential to raise tax revenues considerably). The exception is meat and poultry, suggesting that the inclusion of meat and poultry in the tax base may be viewed as an effective emissions reduction policy. Because our selection of unhealthy and environmentally unfriendly food categories is subjective and somewhat arbitrary, we also provide a detailed list of tax revenues and compensation payments for each food category (see Tables A.1 and A.2 in the Appendix) to allow readers to "build their own tax reform" by selecting the categories that they think should be taxed.

\subsection{Changes in Household Consumption: Comparing Alternative Reform Scenarios}

To study the impact of alternative GST reform scenarios on household consumption, we calculate the change in household consumption resulting from a change in after-tax prices, using the elasticity estimates presented in Table 2. Figure 1 provides an example of how the change in 
household consumption can be derived from elasticity estimates. Assuming a perfectly elastic supply curve and considering an overall elasticity of -0.230 for products that attract GST (see column (2) of Table 2), an increase in the GST rate from 10\% to $15 \%$ would increase prices by $(1.15-1.10) / 1.10 \approx 4.55 \%$. Consequently, the quantity consumed would change by $-0.230 \times 0.455 \approx-1.047 \%$. We can perform similar calculations for GST-free categories to study the consequences of broadening the tax base.

[Figure 1 about here.]

Table 4 provides a summary of the impact of alternative reform scenarios on household consumption. We use both Homescan and HES data to perform our analysis because the sample means obtained from HES data are more likely to be representative of the Australian population than those obtained from the Homescan survey. However, all results presented in Table 4 are based on the elasticity estimates of the Homescan survey, which allows us to exploit variation in prices and quantities at a much more detailed level than the HES. The HES numbers in Table 4 indicate that average households in Australia spend $\$ 6,964$ on food annually. Only a relatively small fraction $(\$ 1,851)$ of that amount includes GST. Moreover, Australian households spend on average $\$ 1,874$ on the (currently GST-free) food categories that we consider as unhealthy or environmentally unfriendly. Low-income households spend on average about $\$ 2,000$ (almost 30\%) less on food than the average Australian household but the distribution across items that do or do not attract GST does not seem to depend on income: About $25 \%$ of the spending of both groups is on food that attracts GST.

Given these numbers, we may examine the implications of a GST reform for household consumption. The results based on HES (in combination with the elasticity estimates of the Homescan survey) reveal that broadening the GST base to include selected food categories (Reform A) would reduce average household consumption by $\$ 53$ annually, while food consumption of low-income households would decline by $\$ 38$. Broadening the tax base to include all food categories (Reform B) would have a much larger impact on household consumption. Specifically, Reform B would reduce average household consumption by $\$ 244$ (0.26\% of household income), while average consumption of low-income households would be reduced by $\$ 161$ ( $0.53 \%$ of household income).

[Table 4 about here.] 
Interestingly, increasing the rate of the GST from $10 \%$ to $15 \%$ without broadening the base (Reform C) would not have a big impact on household consumption (average consumption would decline by $\$ 19$; low-income households would reduce consumption by $\$ 13)$. In contrast, increasing the rate and broadening the tax base to selected food categories (Reform D) would have a sizeable impact on household consumption (average consumption would drop by $\$ 99$; low-income households would spend $\$ 70$ less). Increasing the rate of the GST to $15 \%$ and broadening the tax base to all food categories (Reform E) would reduce average household consumption by $\$ 356$, while low-income households would reduce consumption by $\$ 255$. The numbers at the bottom of Table 4 reveal that even the changes in household consumption induced by a major GST reform (such as Reform E) would still be relatively small (less than $1 \%$ of household income).

\subsection{GST Revenue}

Table 5 includes the estimates of the GST revenues associated with the five reform scenarios discussed above. Our estimates based on HES data indicate that broadening the base to selected food categories alone (Reform A) would raise tax revenues by about $\$ 1.6$ billion, indicating that a GST reform that focuses on taxing unhealthy and environmentally unfriendly products would be beneficial from a fiscal policy perspective. Increasing the rate to $15 \%$

and expanding the base to selected food categories (Reform D) would increase revenues by about $\$ 3.1$ billion. Broadening the base to all food categories and increasing the GST rate to $15 \%$ (Reform E) would increase tax revenues by about $\$ 7.1$ billion.

[Table 5 about here.]

Overall, the numbers in Table 5 reveal that a reform of the GST on food could raise tax revenues considerably. Broadening the base alone (Reform B) would raise revenues by up to $\$ 4.4$ billion, while increasing the GST rate without broadening the base (Reform C) would increase revenues by $\$ 726$ million.

\subsection{Compensating Low-Income Households}

The payments that would be required to compensate low-income households for the losses associated with a GST reform are presented in Table 6. These numbers are based on the 
compensating variation (see Section 3.3) and denote the amount that would be needed to move consumers back to their original welfare levels before the reform. For simplicity, we assume that consumers fully spend the compensation payments they receive to return to their original welfare levels, i.e. they cannot decide to use compensation payments for other purposes (such as the consumption of other goods). Shopping vouchers could be used to implement a policy that is consistent with this type of compensation.

[Table 6 about here.]

The HES results in Table 6 indicate that it would cost $\$ 481$ million to compensate lowincome households for broadening the tax base to selected food categories (Reform A). This figure is considerably lower than the additional tax revenues of $\$ 1.6$ billion resulting from Reform A (see Table 5). Broadening the tax base to all categories (Reform B) would require a considerable amount ( $\$ 1,3$ billion) to compensate low-income households, about $30 \%$ of the additional tax revenues obtained from the reform. In contrast, only about $27 \%$ of the additional tax revenues would be needed to compensate low-income households if the GST rate would be increased to $15 \%$ without broadening the base (Reform C). Expanding the base to selected food categories and increasing the GST rate to $15 \%$ (Reform D) appears to be a sensible policy, which would require about $30 \%$ of the additional tax revenue to compensate lowincome households. Increasing the rate to $15 \%$ and broadening the base to all food categories (Reform E) would yield tax revenues of about $\$ 7.1$ billion and require almost $\$ 2.2$ billion to compensate low-income households (about 30\% of the additional revenues). On balance, these findings indicate that there is considerable scope to raise revenue by a reform of the GST on food.

\section{Conclusions}

This paper examines the potential impact of changes in the GST on household food consumption. We use data from the Nielsen Homescan Survey of households in Australia to estimate the price elasticity of demand for food and calculate tax revenues that would result from alternative GST reform scenarios. We also study the compensating variation to determine the payments that would be required to compensate low-income households (we focus on the 
bottom $40 \%$ of the income distribution) for their loss in consumption resulting from a GST reform.

We find that there is considerable scope for broadening the tax base and increasing the rate, even if the bottom $40 \%$ of the households were compensated for the loss in consumption associated with a GST reform. Our analysis reveals that imposing a GST rate of $15 \%$ on all food categories would raise up to $\$ 7.1$ billion, while up to $\$ 2.2$ billion would be required to compensate low-income households. We also present the results of a reform proposal that would involve broadening the base to include selected (unhealthy and environmentally unfriendly) food categories and increase the GST rate to $15 \%$, which would generate revenues of about $\$ 3.1$ billion and require $\$ 922$ million to compensate low-income households. These results illustrate that a reform of the GST on food in combination with a compensation of lowincome households would reduce fiscal pressures considerably while addressing issues related to the regressive nature of the tax. 


\section{Tables and Figures}

Table 1: WeEkly CONSUmption, QUANTity (IN KG/Lt) AND PRice (IN \$) HOMESCAN SURVEY, 2014

\begin{tabular}{|c|c|c|c|c|c|}
\hline & \multicolumn{2}{|c|}{ Quantity } & \multicolumn{2}{|c|}{ Price } & \multirow[b]{2}{*}{$\mathrm{N}$} \\
\hline & Mean & SD & Mean & SD & \\
\hline \multicolumn{6}{|l|}{ GST-free categories } \\
\hline Bread & 0.56 & 0.51 & 4.65 & 2.72 & 8,275 \\
\hline Flour & 0.14 & 0.20 & 1.86 & 1.57 & 6,074 \\
\hline Cereals, pasta and rice & 0.60 & 0.51 & 5.52 & 1.93 & 8,339 \\
\hline Meat and poultry & 1.52 & 1.22 & 9.65 & 2.54 & 8,323 \\
\hline Fish and seafood & 0.12 & 0.14 & 18.12 & 7.73 & 7,305 \\
\hline Canned and bottled fish and seafood & 0.08 & 0.10 & 11.49 & 4.82 & 7,069 \\
\hline Fresh eggs & 0.14 & 0.16 & 6.70 & 6.91 & 6,998 \\
\hline Fresh milk & 2.10 & 2.07 & 1.40 & 1.52 & 8,230 \\
\hline Cheese & 0.30 & 0.33 & 11.22 & 5.80 & 8,277 \\
\hline Butter, oil and cream & 0.37 & 0.29 & 6.39 & 2.48 & 8,326 \\
\hline Yogurt & 0.31 & 0.35 & 6.55 & 2.94 & 7,665 \\
\hline Dairy products & 0.08 & 0.12 & 5.17 & 2.34 & 5,982 \\
\hline Fresh fruit & 1.33 & 1.36 & 4.20 & 1.47 & 8,319 \\
\hline Canned and frozen fruit and nuts & 0.15 & 0.20 & 7.20 & 3.40 & 7,720 \\
\hline Fresh vegetables & 1.55 & 1.24 & 4.16 & 1.57 & 8,343 \\
\hline Frozen vegetables & 0.46 & 0.43 & 3.76 & 1.11 & 8,280 \\
\hline Sugar, marmalade, jams and syrups & 0.19 & 0.23 & 2.44 & 1.71 & 7,654 \\
\hline Honey & 0.03 & 0.04 & 12.26 & 6.57 & 4,173 \\
\hline Spreads and dips & 0.04 & 0.06 & 12.76 & 5.22 & 6,884 \\
\hline Canned spaghetti and baked beans & 0.11 & 0.13 & 3.03 & 1.05 & 6,596 \\
\hline Packaged waters & 0.62 & 2.27 & 0.92 & 0.88 & 5,133 \\
\hline Tea & 0.02 & 0.03 & 24.12 & 23.25 & 4,078 \\
\hline Coffee & 0.05 & 0.06 & 33.57 & 14.82 & 6,838 \\
\hline Vegetable juice and packed soup & 0.09 & 0.13 & 6.14 & 3.96 & 7,223 \\
\hline Canned and bottled baby foods & 0.10 & 0.19 & 17.94 & 9.48 & 1,418 \\
\hline Sauces and salad dressings & 0.42 & 0.32 & 6.14 & 2.10 & 8,346 \\
\hline \multicolumn{6}{|l|}{ GST categories } \\
\hline Cake, biscuit, pudding and bread mixes & 0.30 & 0.26 & 10.34 & 2.48 & 8,328 \\
\hline Spices and other food additives & 0.05 & 0.07 & 7.31 & 3.78 & 6,121 \\
\hline Confectionery (including ice cream) & 0.63 & 0.76 & 7.66 & 4.11 & 8,336 \\
\hline Frozen prepared meals & 0.13 & 0.19 & 11.83 & 3.82 & 7,306 \\
\hline Soft drinks & 2.01 & 2.79 & 1.51 & 0.63 & 7,897 \\
\hline Mixed fruit juice & 0.73 & 0.97 & 1.93 & 1.21 & 7,497 \\
\hline Cordials & 0.19 & 0.28 & 2.82 & 1.60 & 4,743 \\
\hline
\end{tabular}


TABle 2: Price Elasticity estimates By Food Category Homescan SuRvey, 2014

\begin{tabular}{|c|c|c|c|c|}
\hline & \multicolumn{2}{|c|}{ AIDS Model } & \multicolumn{2}{|c|}{ QUAIDS Model } \\
\hline & $\begin{array}{r}\text { OLS } \\
(1)\end{array}$ & $\begin{array}{l}\text { IV } \\
(2)\end{array}$ & $\begin{array}{r}\text { OLS } \\
(3)\end{array}$ & $\begin{array}{l}\mathrm{IV} \\
(4)\end{array}$ \\
\hline All categories & $\begin{array}{c}-0.390^{* * *} \\
(0.011)\end{array}$ & $\begin{array}{l}-0.416^{* * *} \\
(0.020)\end{array}$ & $\begin{array}{l}-0.425^{* * *} \\
(0.011)\end{array}$ & $\begin{array}{c}-0.429^{* * *} \\
(0.018)\end{array}$ \\
\hline GST-free categories & $\begin{array}{l}-0.411^{* * *} \\
(0.012)\end{array}$ & $\begin{array}{c}-0.439^{* * *} \\
(0.022)\end{array}$ & $\begin{array}{l}-0.445^{* * *} \\
(0.012)\end{array}$ & $\begin{array}{c}-0.452^{* * *} \\
(0.023)\end{array}$ \\
\hline Bread & $\begin{array}{l}-0.033 \\
(0.036)\end{array}$ & $\begin{array}{c}0.111 \\
(0.116)\end{array}$ & $\begin{array}{l}-0.100^{* * *} \\
(0.035)\end{array}$ & $\begin{array}{c}0.108 \\
(0.112)\end{array}$ \\
\hline Flour & $\begin{array}{c}-0.240^{* *} \\
(0.108)\end{array}$ & $\begin{array}{l}-0.243^{* *} \\
(0.111)\end{array}$ & $\begin{array}{l}-0.223^{*} \\
(0.122)\end{array}$ & $\begin{array}{c}-0.234^{*} \\
(0.124)\end{array}$ \\
\hline Cereals, pasta and rice & $\begin{array}{c}-0.265^{* * *} \\
(0.019)\end{array}$ & $\begin{array}{l}-0.309^{* * *} \\
(0.013)\end{array}$ & $\begin{array}{l}-0.288^{* * *} \\
(0.019)\end{array}$ & $\begin{array}{c}-0.304^{* * *} \\
(0.014)\end{array}$ \\
\hline Meat and poultry & $\begin{array}{l}-0.394^{* * *} \\
(0.029)\end{array}$ & $\begin{array}{c}-0.462^{* * *} \\
(0.043)\end{array}$ & $\begin{array}{l}-0.430^{* * *} \\
(0.029)\end{array}$ & $\begin{array}{c}-0.482^{* * *} \\
(0.054)\end{array}$ \\
\hline Fish and seafood & $\begin{array}{c}-0.222^{* * *} \\
(0.026)\end{array}$ & $\begin{array}{c}-0.715^{* *} \\
(0.291)\end{array}$ & $\begin{array}{c}-0.280^{* * *} \\
(0.020)\end{array}$ & $\begin{array}{l}-0.702^{* * *} \\
(0.267)\end{array}$ \\
\hline Canned and bottled fish and seafood & $\begin{array}{l}-0.075 \\
(0.082)\end{array}$ & $\begin{array}{l}-0.130^{*} \\
(0.073)\end{array}$ & $\begin{array}{l}-0.068 \\
(0.087)\end{array}$ & $\begin{array}{l}-0.124 \\
(0.077)\end{array}$ \\
\hline Fresh eggs & $\begin{array}{l}-0.133^{* * *} \\
(0.051)\end{array}$ & $\begin{array}{l}-0.174 \\
(3.171)\end{array}$ & $\begin{array}{c}-0.136^{* * *} \\
(0.036)\end{array}$ & $\begin{array}{l}-0.167 \\
(1.122)\end{array}$ \\
\hline Fresh milk & $\begin{array}{c}0.135 \\
(0.141)\end{array}$ & $\begin{array}{c}0.392 \\
(5.342)\end{array}$ & $\begin{array}{c}0.026 \\
(0.144)\end{array}$ & $\begin{array}{c}0.436 \\
(0.710)\end{array}$ \\
\hline Cheese & $\begin{array}{l}-0.119 \\
(0.088)\end{array}$ & $\begin{array}{l}-0.123 \\
(0.090)\end{array}$ & $\begin{array}{l}-0.173^{* *} \\
(0.086)\end{array}$ & $\begin{array}{l}-0.161^{*} \\
(0.093)\end{array}$ \\
\hline Butter, oil and cream & $\begin{array}{c}-0.173^{* * *} \\
(0.027)\end{array}$ & $\begin{array}{c}-0.176^{* * *} \\
(0.032)\end{array}$ & $\begin{array}{c}-0.215^{* * *} \\
(0.023)\end{array}$ & $\begin{array}{l}-0.192^{* * *} \\
(0.032)\end{array}$ \\
\hline Yogurt & $\begin{array}{c}-0.232^{* * *} \\
(0.031)\end{array}$ & $\begin{array}{l}-0.238 \\
(0.176)\end{array}$ & $\begin{array}{c}-0.283^{* * *} \\
(0.026)\end{array}$ & $\begin{array}{l}-0.241 \\
(0.256)\end{array}$ \\
\hline Dairy products & $\begin{array}{l}-0.416^{* * *} \\
(0.023)\end{array}$ & $\begin{array}{c}-0.401^{* * *} \\
(0.037)\end{array}$ & $\begin{array}{c}-0.462^{* * *} \\
(0.030)\end{array}$ & $\begin{array}{l}-0.418^{* * *} \\
(0.029)\end{array}$ \\
\hline Fresh fruit & $\begin{array}{c}-0.429^{* * *} \\
(0.019)\end{array}$ & $\begin{array}{l}-0.441^{* * *} \\
(0.026)\end{array}$ & $\begin{array}{c}-0.463^{* * *} \\
(0.017)\end{array}$ & $\begin{array}{l}-0.450^{* * *} \\
(0.028)\end{array}$ \\
\hline Canned and frozen fruit and nuts & $\begin{array}{l}-0.275^{* * *} \\
(0.025)\end{array}$ & $\begin{array}{c}-0.276^{\text {*** }} \\
(0.033)\end{array}$ & $\begin{array}{l}-0.296^{* * *} \\
(0.022)\end{array}$ & $\begin{array}{c}-0.281^{* * *} \\
(0.025)\end{array}$ \\
\hline Fresh vegetables & $\begin{array}{c}-0.478^{* * *} \\
(0.014)\end{array}$ & $\begin{array}{l}-0.490^{* * *} \\
(0.040)\end{array}$ & $\begin{array}{c}-0.501^{* * *} \\
(0.015)\end{array}$ & $\begin{array}{c}-0.495^{* * *} \\
(0.047)\end{array}$ \\
\hline Frozen vegetables & $\begin{array}{l}-0.202^{* * *} \\
(0.020)\end{array}$ & $\begin{array}{l}-0.210^{* * *} \\
(0.022)\end{array}$ & $\begin{array}{c}-0.249^{* * *} \\
(0.022)\end{array}$ & $\begin{array}{c}-0.233^{* * *} \\
(0.023)\end{array}$ \\
\hline Sugar, marmalade, jams and syrups & $\begin{array}{l}-0.036 \\
(0.047)\end{array}$ & $\begin{array}{l}-0.038 \\
(0.046)\end{array}$ & $\begin{array}{l}-0.078^{* *} \\
(0.038)\end{array}$ & $\begin{array}{l}-0.044 \\
(0.047)\end{array}$ \\
\hline Honey & $\begin{array}{l}-0.041 \\
(0.065)\end{array}$ & $\begin{array}{l}-0.592 \\
(1.091)\end{array}$ & $\begin{array}{c}0.009 \\
(0.089)\end{array}$ & $\begin{array}{l}-0.473 \\
(0.995)\end{array}$ \\
\hline Spreads and dips & $\begin{array}{c}-0.191^{* * *} \\
(0.034)\end{array}$ & $\begin{array}{l}-0.146 \\
(0.342)\end{array}$ & $\begin{array}{c}-0.285^{* * *} \\
(0.034)\end{array}$ & $\begin{array}{l}-0.199^{* *} \\
(0.088)\end{array}$ \\
\hline Canned spaghetti and baked beans & $\begin{array}{c}-0.249^{* * *} \\
(0.034)\end{array}$ & $\begin{array}{c}-0.276^{* * *} \\
(0.044)\end{array}$ & $\begin{array}{c}-0.278^{* * *} \\
(0.036)\end{array}$ & $\begin{array}{c}-0.285^{* * *} \\
(0.039)\end{array}$ \\
\hline
\end{tabular}


TABle 2 (CONTINUED)

\begin{tabular}{|c|c|c|c|c|}
\hline & \multicolumn{2}{|c|}{ AIDS Model } & \multicolumn{2}{|c|}{ QUAIDS Model } \\
\hline & $\begin{array}{r}\text { OLS } \\
(1)\end{array}$ & $\begin{array}{l}\text { IV } \\
(2)\end{array}$ & $\begin{array}{r}\text { OLS } \\
(3)\end{array}$ & $\begin{array}{l}\text { IV } \\
(4)\end{array}$ \\
\hline Packaged waters & $\begin{array}{l}-0.150 \\
(0.107)\end{array}$ & $\begin{array}{l}-0.153 \\
(0.104)\end{array}$ & $\begin{array}{l}-0.164 \\
(0.100)\end{array}$ & $\begin{array}{l}-0.149 \\
(0.116)\end{array}$ \\
\hline Tea & $\begin{array}{c}-0.327^{* * *} \\
(0.049)\end{array}$ & $\begin{array}{c}-0.368^{* * *} \\
(0.050)\end{array}$ & $\begin{array}{c}-0.338^{* * *} \\
(0.056)\end{array}$ & $\begin{array}{c}-0.360^{* * *} \\
(0.051)\end{array}$ \\
\hline Coffee & $\begin{array}{c}-0.266^{* * *} \\
(0.036)\end{array}$ & $\begin{array}{l}-0.299^{* * *} \\
(0.042)\end{array}$ & $\begin{array}{l}-0.307^{* * *} \\
(0.036)\end{array}$ & $\begin{array}{c}-0.303^{* * *} \\
(0.043)\end{array}$ \\
\hline Vegetable juice and packed soup & $\begin{array}{l}-0.013 \\
(0.052)\end{array}$ & $\begin{array}{l}-0.022 \\
(0.057)\end{array}$ & $\begin{array}{l}-0.043 \\
(0.054)\end{array}$ & $\begin{array}{l}-0.052 \\
(0.380)\end{array}$ \\
\hline Canned and bottled baby foods & $\begin{array}{c}-0.678^{* * *} \\
(0.094)\end{array}$ & $\begin{array}{l}-0.613^{* * *} \\
(0.163)\end{array}$ & $\begin{array}{c}-0.706^{* * *} \\
(0.086)\end{array}$ & $\begin{array}{c}-0.695^{* * *} \\
(0.251)\end{array}$ \\
\hline Sauces and salad dressings & $\begin{array}{c}-0.198^{* * *} \\
(0.019)\end{array}$ & $\begin{array}{c}-0.216^{* * *} \\
(0.015)\end{array}$ & $\begin{array}{c}-0.232^{* * *} \\
(0.015)\end{array}$ & $\begin{array}{l}-0.222^{* * *} \\
(0.015)\end{array}$ \\
\hline GST categories & $\begin{array}{c}-0.214^{* * *} \\
(0.018)\end{array}$ & $\begin{array}{l}-0.230^{* * *} \\
(0.022)\end{array}$ & $\begin{array}{l}-0.247^{* * *} \\
(0.015)\end{array}$ & $\begin{array}{c}-0.242^{* * *} \\
(0.019)\end{array}$ \\
\hline Cake, biscuit, pudding and bread mixes & $\begin{array}{c}-0.215^{* * *} \\
(0.020)\end{array}$ & $\begin{array}{c}-0.220^{* * *} \\
(0.029)\end{array}$ & $\begin{array}{c}-0.253^{* * *} \\
(0.021)\end{array}$ & $\begin{array}{c}-0.226^{* * *} \\
(0.027)\end{array}$ \\
\hline Spices and other food additives & $\begin{array}{c}-0.094^{* * *} \\
(0.032)\end{array}$ & $\begin{array}{c}-0.119^{* * *} \\
(0.039)\end{array}$ & $\begin{array}{c}-0.129^{* * *} \\
(0.036)\end{array}$ & $\begin{array}{c}-0.139^{* * *} \\
(0.040)\end{array}$ \\
\hline Confectionery (including ice cream) & $\begin{array}{l}-0.138^{* * *} \\
(0.033)\end{array}$ & $\begin{array}{l}-0.163^{* * *} \\
(0.032)\end{array}$ & $\begin{array}{l}-0.164^{* * *} \\
(0.027)\end{array}$ & $\begin{array}{l}-0.163^{* * *} \\
(0.026)\end{array}$ \\
\hline Frozen prepared meals & $\begin{array}{l}-0.216^{* * *} \\
(0.024)\end{array}$ & $\begin{array}{l}-0.259^{* * *} \\
(0.044)\end{array}$ & $\begin{array}{c}-0.243^{* * *} \\
(0.025)\end{array}$ & $\begin{array}{l}-0.255^{* *} \\
(0.124)\end{array}$ \\
\hline Soft drinks & $\begin{array}{c}-0.383^{* * *} \\
(0.029)\end{array}$ & $\begin{array}{l}-0.381^{* * *} \\
(0.032)\end{array}$ & $\begin{array}{l}-0.410^{* * *} \\
(0.026)\end{array}$ & $\begin{array}{c}-0.421^{* * *} \\
(0.026)\end{array}$ \\
\hline Mixed fruit juice & $\begin{array}{l}-0.226^{* * *} \\
(0.045)\end{array}$ & $\begin{array}{l}-0.274^{* *} \\
(0.114)\end{array}$ & $\begin{array}{c}-0.273^{* * *} \\
(0.051)\end{array}$ & $\begin{array}{l}-0.298^{*} \\
(0.165)\end{array}$ \\
\hline Cordials & $\begin{array}{c}-0.263^{* * *} \\
(0.061)\end{array}$ & $\begin{array}{l}-0.248^{* * *} \\
(0.060)\end{array}$ & $\begin{array}{l}-0.331^{* * *} \\
(0.035)\end{array}$ & $\begin{array}{l}-0.262 \\
(0.216)\end{array}$ \\
\hline
\end{tabular}

Note: Robust standard errors (reported in parentheses) were clustered at the household level.

${ }^{*} \mathrm{p}<0.10,{ }^{* *} \mathrm{p}<0.05,{ }^{* * *} \mathrm{p}<0.01$. 
Table 3: Ranking of food Categories by elasticity - Homescan Survey, 2014

\begin{tabular}{|c|c|c|}
\hline \multirow[b]{2}{*}{ Rank } & \multicolumn{2}{|c|}{ Category } \\
\hline & OLS & IV \\
\hline \multicolumn{3}{|c|}{ GST-free categories } \\
\hline \multicolumn{3}{|c|}{$\underline{\eta_{d}<-0.30}$} \\
\hline 1 & $\overline{\text { Canned and bottled baby foods }}$ & Fish and seafood \\
\hline 2 & Fresh vegetables & Canned and bottled baby foods \\
\hline 3 & Fresh fruit & Honey \\
\hline 4 & Dairy products & Fresh vegetables \\
\hline 5 & Meat and poultry & Meat and poultry \\
\hline 6 & Tea & Fresh fruit \\
\hline 7 & - & Dairy products \\
\hline 8 & - & Tea \\
\hline 9 & - & Cereals, pasta and rice \\
\hline \multicolumn{3}{|c|}{$\underline{\eta_{d}}>-0.30$} \\
\hline 7 & Canned and frozen fruit and nuts & - \\
\hline 8 & Coffee & - \\
\hline 9 & Cereals, pasta and rice & - \\
\hline 10 & Canned spaghetti and baked beans & Coffee \\
\hline 11 & Flour & Canned and frozen fruit and nuts \\
\hline 12 & Yogurt & Canned spaghetti and baked beans \\
\hline 13 & Fish and seafood & Flour \\
\hline 14 & Frozen vegetables & Yogurt \\
\hline 15 & Sauces and salad dressings & Sauces and salad dressings \\
\hline 16 & Spreads and dips & Frozen vegetables \\
\hline 17 & Butter, oil and cream & Butter, oil and cream \\
\hline 18 & Packaged waters & Fresh eggs \\
\hline 19 & Fresh eggs & Packaged waters \\
\hline 20 & Cheese & Spreads and dips \\
\hline 21 & Canned and bottled fish and seafood & Canned and bottled fish and seafood \\
\hline 22 & Honey & Cheese \\
\hline 23 & Sugar, marmalade, jams and syrups & Sugar, marmalade, jams and syrups \\
\hline 24 & Bread & Vegetable juice and packed soup \\
\hline 25 & Vegetable juice and packed soup & Bread \\
\hline 26 & Fresh milk & Fresh milk \\
\hline \multicolumn{3}{|c|}{ GST categories } \\
\hline \multicolumn{3}{|c|}{$\underline{\eta_{d}<-0.30}$} \\
\hline 1 & Soft drinks & Soft drinks \\
\hline \multicolumn{3}{|c|}{$\eta_{d}>-0.30$} \\
\hline 2 & $\overline{\text { Cordials }}$ & Mixed fruit juice \\
\hline 3 & Mixed fruit juice & Frozen prepared meals \\
\hline 4 & Frozen prepared meals & Cordials \\
\hline 5 & Cake, biscuit, pudding and bread mixes & Cake, biscuit, pudding and bread mixes \\
\hline 6 & Confectionery (including ice cream) & Confectionery (including ice cream) \\
\hline 7 & Spices and other food additives & Spices and other food additives \\
\hline
\end{tabular}


Figure 1: ImPACT OF RAISING THE GST RATE FROM 10\% TO $15 \%$ WHEN THE SUPPLY CURVE IS PERFECTLY ELASTIC

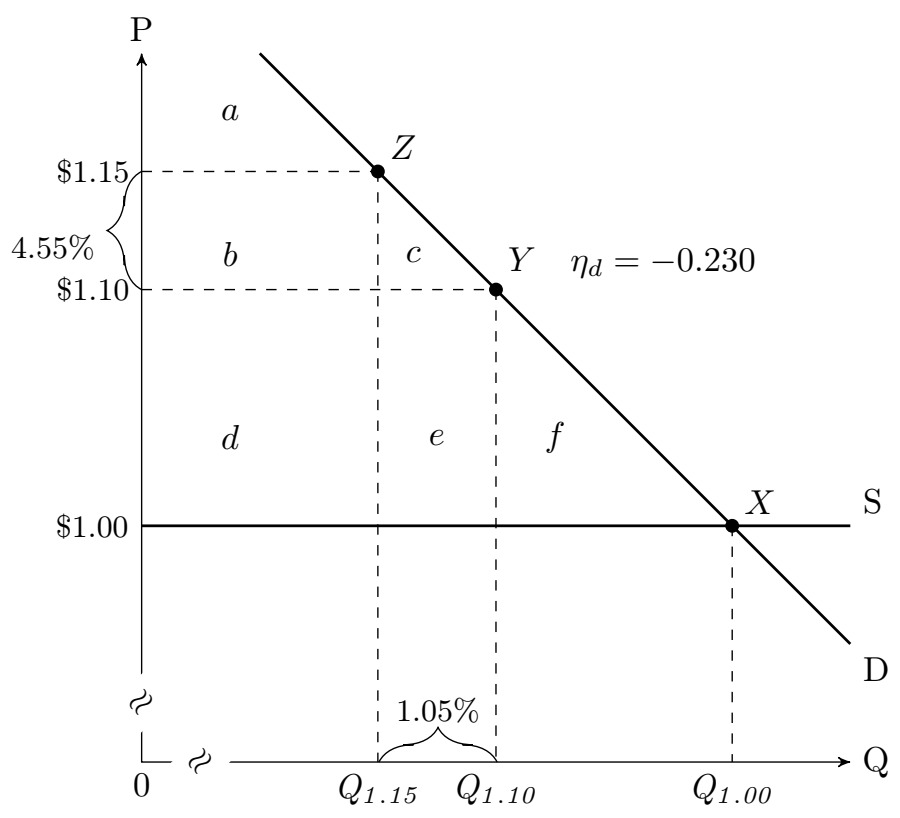

TABle 4: The IMPACT OF ALTERNATIVE GST REFORM SCENARIOS ON FOOD CONSUMPTION

\begin{tabular}{|c|c|c|c|c|}
\hline & \multicolumn{2}{|c|}{ Homescan, 2014} & \multicolumn{2}{|c|}{ HES, 2010} \\
\hline & $\begin{array}{l}\text { Low-income } \\
\text { households }\end{array}$ & All & $\begin{array}{l}\text { Low-income } \\
\text { households }\end{array}$ & All \\
\hline Mean food consumption $(\$)$ & 3,941 & 4,443 & 4,903 & 6,964 \\
\hline GST categories $(\$)$ & 1,012 & 1,102 & 1,227 & 1,851 \\
\hline GST free categories $(\$)$ & 2,929 & 3,340 & 3,676 & 5,112 \\
\hline Selected GST free categories $(\$)^{\dagger}$ & 1,083 & 1,230 & 1,353 & 1,874 \\
\hline \multicolumn{5}{|l|}{ Mean change in food consumption $(\$)$} \\
\hline A. Broaden base to selected categories & -30.54 & -34.70 & -38.15 & -52.85 \\
\hline B. Broaden base to all categories & -128.59 & -146.64 & -161.38 & -224.42 \\
\hline C. Increase rate on GST categories to $15 \%$ & -10.47 & -11.41 & -13.00 & -19.25 \\
\hline D. Increase rate and broaden base to selected categories & -56.28 & -63.45 & -70.23 & -98.52 \\
\hline E. Increase rate and broaden base to all categories & -203.35 & -231.37 & -254.88 & -355.62 \\
\hline Mean household income $(\$ 1,000)$ & 34.67 & 80.15 & 30.59 & 87.77 \\
\hline \multicolumn{5}{|l|}{ Mean change in food consumption as a percentage of income } \\
\hline A. Broaden base to selected categories & -0.09 & -0.04 & -0.12 & -0.09 \\
\hline B. Broaden base to all categories & -0.37 & -0.18 & -0.53 & -0.26 \\
\hline C. Increase rate on GST categories to $15 \%$ & -0.03 & -0.01 & -0.04 & -0.02 \\
\hline D. Increase rate and broaden base to selected categories & -0.23 & -0.08 & -0.23 & -0.11 \\
\hline E. Increase rate and broaden base to all categories & -0.59 & -0.29 & -0.83 & -0.41 \\
\hline
\end{tabular}

Note: Low-income households refer to the bottom $40 \%$ of the income distribution.

$\dagger$ Selected categories include: (i) Meat and poultry, (ii) canned and frozen fruit and nuts, (iii) canned spaghetti and baked beans, (iv) sauces and salad dressings, (v) spreads and dips, (vi) butter, oil and cream, (vii) packaged waters, (viii) canned and bottled fish and seafood, and (ix) sugar, marmalade, jams and syrups. 
TABle 5: Estimate of additional GST Revenues RESUlting From ALTERNATIVE REFORM SCENARIOS (IN \$ MILLION)

\begin{tabular}{lcc}
\hline & Homescan, 2014 & HES, 2010 \\
\hline A. Broaden base to selected categories & 1,064 & 1,621 \\
B. Broaden base to all categories & 2,843 & 4,351 \\
C. Increase rate on GST categories to 15\% & 432 & 726 \\
D. Increase rate and broaden base to selected categories & 2,006 & 3,122 \\
E. Increase rate and broaden base to all categories & 4,599 & 7,102 \\
\hline
\end{tabular}

Note: Current revenue with Homescan 2014 is $\$ 892$ million and HES 2010 is $\$ 1,498$ million.

TABle 6: COMPEnSATion PAYMents to LOW-INCOME hOUSEHOldS

\begin{tabular}{lcc}
\hline & Homescan, 2014 & HES, 2010 \\
\hline Per household (\$) & & \\
A. Broaden base to selected categories & 108 & 135 \\
B. Broaden base to all categories & 293 & 368 \\
C. Increase rate on GST categories to 15\% & 46 & 56 \\
D. Increase rate and broaden base to selected categories & 208 & 259 \\
E. Increase rate and broaden base to all categories & 485 & 607 \\
Fiscal cost (\$ million) & & \\
A. Broaden base to selected categories & 386 & 481 \\
B. Broaden base to all categories & 1,043 & 1,310 \\
C. Increase rate on GST categories to 15\% & 164 & 199 \\
D. Increase rate and broaden base to selected categories & 742 & 922 \\
E. Increase rate and broaden base to all categories & 1,728 & 2,162 \\
\hline
\end{tabular}




\section{References}

Andreyeva, T., Long, M. W., \& Brownell, K. D. (2010). The impact of food prices on consumption: A systematic review of research on the price elasticity of demand for food. American journal of public health, 100(2), 216-222.

Australian Bureau of Statistics (2015). Household and Family Projections, Australia, 2011 to 2036. Available from: http://www.abs.gov.au/AUSSTATS/abs@.nsf/Lookup/3236. OMain+Features12011\%20to\%202036?OpenDocument [Accessed: 13 February 2017].

Banks, J., Blundell, R., \& Lewbel, A. (1997). Quadratic Engel Curves and Consumer Demand. The Review of Economics and Statistics, 79(4), 527-539.

Bhalotra, S., \& Attfield, C. (1998). Intrahousehold Resource Allocation in Rural Pakistan: A Semiparametric Analysis. Journal of Applied Econometrics, 13(5), 463-480.

Blundell, R., Chen, X., \& Kristensen, D. (2007). Semi-nonparametric IV Estimation of Shape-invariant Engel Curves. Econometrica, 75(6), 1613-1669.

Blundell, R., Duncan, A., \& Pendakur, K. (1998). Semiparametric Estimation and Consumer Demand. Journal of Applied Econometrics, 13(5), 435-461.

Chetty, R., Looney, A., \& Kroft, K. (2009). Salience and Taxation: Theory and Evidence. American Economic Review, 99, 1145-1177.

Clements, K. W., \& Si, J. W. (2016). Price Elasticities of Food Demand: Compensated vs. Uncompensated. Health Economics, 25, 1403-1408.

Commonwealth of Australia (2015). Goods and Services Tax: Distributional Analysis and Indicative Reform Scenario. Technical Report 05, Parliamentary Budget Office, Commonwealth of Australia, Canberra, Australia.

Commonwealth of Australia (2016a). Mid-Year Economic and Fiscal Outlook, 2016-17. Tech. rep., Commonwealth of Australia, Canberra. 
Commonwealth of Australia (2016b). Final Budget Outcome, 2015-16. Technical report, Treasurer and Minister for Finance, Commonwealth of Australia, Canberra, Australia.

Commonwealth of Australia (2016c). Goods and Services Tax, Industry Issue. Technical report, Australian Taxation Office, Commonwealth of Australia, Canberra, Australia.

Deaton, A., \& Muellbauer, J. (1980). An Almost Ideal Demand System. The American Economic Review, 70(3), 312-326.

Ferreira, F. H. G., Fruttero, A., Leite, P. G., \& Lucchetti, L. R. (2013). Rising Food Prices and Household Welfare: Evidence from Brazil in 2008. Journal of Agricultural Economics, $64(1), 151-176$.

Golan, A., Perloff, J. M., \& Shen, E. Z. (2001). Estimating a Demand System with Nonnegativity Constraints: Mexican Meat Demand. Review of Economics and Statistics, 83(3), $541-550$

Li, S., Linn, J., \& Muehlegger, E. (2014). Gasoline Taxes and Consumer Behavior. American Economic Journal: Economic Policy, 6, 302-342.

Liviatan, N. (1961). Errors in Variables and Engel Curve Analysis. Econometrica, 29(3), $336-362$

Mas-Colell, A., Whinston, M., \& Green, J. (1995). Microeconomic Theory. NY, USA: Oxford University Press.

Nielsen Corporation (2016). Consumer Panels (Nielsen Homescan Shopper Panel). Available from: http://www.nielsen.com/au/en/solutions/measurement/consumerpanels.html [Accessed: 18 November 2016].

OECD (2016). Consumption Tax Trends 2016: VAT/GST and Excise Rates, Trends and Policy Issues. Tech. rep., OECD, Paris.

Phillips, B., \& Taylor, M. (2015). The Distributional Impact of the GST. Technical Report 29, National Centre for Social and Economic Modelling (NATSEM). 
Powell, L. M., Chriqui, J. F., Khan, T., Wada, R., \& Chaloupka, F. J. (2013). Assessing the potential effectiveness of food and beverage taxes and subsidies for improving public health: A systematic review of prices, demand and body weight outcomes. Obesity reviews, $14(2), 110-128$.

Reisch, L., Eberle, U., \& Lorek, S. (2013). Sustainable food consumption: an overview of contemporary issues and policies. Sustainability: Science, Practice, $\&$ Policy, 9(2), 7-25.

Sharma, A., Hauck, K., Hollingsworth, B., \& Siciliani, L. (2014). The Effects of Taxing Sugar-sweetened Beverages Across Different Income Groups. Health Economics, 23(9), $1159-1184$.

Sinning, M. (2016). Budget Forum 2016: The Growth Puzzle. Tech. rep., Austaxpolicy: Tax and Transfer Policy Blog.

Ulubasoglu, M., Mallick, D., Wadud, M., Hone, P., \& Haszler, H. (2016). Food Demand Elasticities for Australia. Australian Journal of Agricultural and Resource Economics, $60(2), 177-195$.

Wirsenius, S., Hedenus, F., \& Mohlin, K. (2011). Greenhouse gas taxes on animal food products: Rationale, tax scheme and climate mitigation effects. Climatic Change, 108(1), $159-184$. 


\section{Appendix}

Table A.1: The impact of Broadening the base (Without increasing the Rate): GST Revenues and Compensation payments (\$ Million) By Category

\begin{tabular}{|c|c|c|c|c|c|}
\hline & \multirow[b]{2}{*}{ Elasticity } & \multicolumn{2}{|c|}{ Homescan Survey, 2014} & \multicolumn{2}{|c|}{ HES, 2010} \\
\hline & & Revenue & Compensation & Revenue & Compensation \\
\hline Bread & 0.000 & 128 & 45 & 325 & 96 \\
\hline Flour & -0.243 & 12 & 5 & 16 & 4 \\
\hline Cereals, pasta and rice & -0.309 & 156 & 52 & 211 & 60 \\
\hline Meat and poultry & -0.462 & 683 & 249 & 1,103 & 328 \\
\hline Fish and seafood & -0.715 & 97 & 38 & 150 & 45 \\
\hline Canned and bottled fish and seafood & 0.000 & 45 & 16 & 66 & 19 \\
\hline Fresh eggs & 0.000 & 44 & 15 & 65 & 20 \\
\hline Fresh milk & 0.000 & 145 & 55 & 306 & 96 \\
\hline Cheese & 0.000 & 166 & 54 & 203 & 52 \\
\hline Butter, oil and cream & -0.176 & 113 & 44 & 113 & 39 \\
\hline Yogurt & 0.000 & 100 & 34 & 111 & 30 \\
\hline Dairy products & -0.401 & 20 & 9 & 73 & 22 \\
\hline Fresh fruit & -0.441 & 271 & 97 & 493 & 145 \\
\hline Canned and frozen fruit and nuts & -0.276 & 54 & 21 & 62 & 22 \\
\hline Fresh vegetables & -0.490 & 310 & 113 & 550 & 163 \\
\hline Frozen vegetables & -0.210 & 82 & 31 & 58 & 20 \\
\hline Sugar, marmalade, jams and syrups & 0.000 & 23 & 9 & 51 & 18 \\
\hline Honey & 0.000 & 17 & 7 & 15 & 5 \\
\hline Spreads and dips & 0.000 & 27 & 10 & 59 & 16 \\
\hline Canned spaghetti and baked beans & -0.276 & 16 & 6 & 16 & 5 \\
\hline Packaged waters & 0.000 & 27 & 11 & 56 & 11 \\
\hline Tea & -0.368 & 17 & 7 & 36 & 12 \\
\hline Coffee & -0.299 & 79 & 34 & 80 & 28 \\
\hline Vegetable juice and packed soup & 0.000 & 28 & 11 & 40 & 13 \\
\hline Canned and bottled baby foods & -0.613 & 80 & 24 & 11 & 2 \\
\hline Sauces and salad dressings & -0.216 & 121 & 43 & 84 & 23 \\
\hline Total & -0.439 & 2,903 & 1,066 & 4,351 & 1,309 \\
\hline
\end{tabular}

Note: Estimated elasticities that are not statistically significant are assumed to be zero. Compensation payments are for households in the bottom $40 \%$ of the household income distribution. 
TABle A.2: The ImpaCt of BROAdening the BASE AND InCREASing the RATE TO $15 \%$ : GST Revenues and Compensation payments (\$ Million) By CATEgory

\begin{tabular}{|c|c|c|c|c|c|}
\hline & \multirow[b]{2}{*}{ Elasticity } & \multicolumn{2}{|c|}{ Homescan Survey, 2014} & \multicolumn{2}{|c|}{ HES, 2010} \\
\hline & & Revenue & Compensation & Revenue & Compensation \\
\hline \multicolumn{6}{|l|}{ GST-free categories } \\
\hline Bread & 0.000 & 193 & 68 & 488 & 145 \\
\hline Flour & -0.243 & 18 & 7 & 23 & 7 \\
\hline Cereals, pasta and rice & -0.309 & 230 & 79 & 311 & 90 \\
\hline Meat and poultry & -0.462 & 998 & 372 & 1,615 & 492 \\
\hline Fish and seafood & -0.715 & 140 & 57 & 217 & 68 \\
\hline Canned and bottled fish and seafood & 0.000 & 67 & 24 & 98 & 29 \\
\hline Fresh eggs & 0.000 & 66 & 23 & 98 & 30 \\
\hline Fresh milk & 0.000 & 217 & 82 & 460 & 144 \\
\hline Cheese & 0.000 & 250 & 81 & 304 & 79 \\
\hline Butter, oil and cream & -0.176 & 169 & 65 & 167 & 59 \\
\hline Yogurt & 0.000 & 150 & 52 & 166 & 44 \\
\hline Dairy products & -0.401 & 29 & 13 & 107 & 33 \\
\hline Fresh fruit & -0.441 & 398 & 146 & 723 & 217 \\
\hline Canned and frozen fruit and nuts & -0.276 & 80 & 32 & 91 & 32 \\
\hline Fresh vegetables & -0.490 & 454 & 170 & 804 & 245 \\
\hline Frozen vegetables & -0.210 & 122 & 47 & 86 & 30 \\
\hline Sugar, marmalade, jams and syrups & 0.000 & 34 & 14 & 76 & 27 \\
\hline Honey & 0.000 & 25 & 11 & 22 & 7 \\
\hline Spreads and dips & 0.000 & 40 & 14 & 88 & 24 \\
\hline Canned spaghetti and baked beans & -0.276 & 24 & 9 & 24 & 8 \\
\hline Packaged waters & 0.000 & 40 & 16 & 85 & 16 \\
\hline Tea & -0.368 & 25 & 10 & 52 & 18 \\
\hline Coffee & -0.299 & 117 & 52 & 118 & 42 \\
\hline Vegetable juice and packed soup & 0.000 & 42 & 16 & 60 & 20 \\
\hline Canned and bottled baby foods & -0.613 & 116 & 36 & 16 & 3 \\
\hline Sauces and salad dressings & -0.216 & 179 & 64 & 124 & 34 \\
\hline Total & -0.439 & 4,262 & 1,601 & 6,377 & 1,964 \\
\hline \multicolumn{6}{|l|}{ GST categories } \\
\hline Cake, biscuit, pudding and bread mixes & -0.220 & 66 & 25 & 173 & 52 \\
\hline Spices and other food additives & -0.119 & 9 & 3 & 34 & 9 \\
\hline Confectionery (including ice cream) & -0.163 & 108 & 41 & 243 & 65 \\
\hline Frozen prepared meals & -0.259 & 35 & 14 & 86 & 26 \\
\hline Soft drinks & -0.381 & 65 & 24 & 126 & 31 \\
\hline Mixed fruit juice & -0.274 & 31 & 11 & 53 & 13 \\
\hline Cordials & -0.248 & 11 & 4 & 10 & 3 \\
\hline Total & -0.230 & 452 & 167 & 726 & 199 \\
\hline
\end{tabular}

Note: See note to Table A.1. 